\title{
A STUDY ON WELFARE MEASURES, AWARENESS AND ITS IMPACT ON QWL OF EMPLOYEES
}

\section{Shaheen Fathima .H}

Jayashree. $\mathbf{M}^{*}$

\author{
Student, Department of Business Administration, C.T.T.E College for \\ Women, Chennai-11
}

Assistant Professor, Department of Business Administration, C.T.T.E College for Women, Chennai-1 1 *Corresponding Author

ABSTRACT Human Resources constitute a most important element of Factors of Production. At the present scenario where business has undergone a paradigm shift in their operations through digital \& Virtual environment, importance of employee's health, safety and motivation in all possible forms to retain the best performer gains more importance. In the light of the above, this paper attempts to study the Welfare measures provided by BGR Energy Systems, an Oil \& Gas Company located in Chennai. The aim of the study is to identify the satisfactory parameters of the welfare measures, through perfect analysis \& interpretation. This study would be helpful for the company and also to improve some welfare and safety activities inside the company.

\section{KEYWORDS :}

\section{Objectives}

The objective of this paper is to study:

- The work environment and welfare measures provided to the employees

- Impact on Organisation and QWL of Employees

- Employee awareness and satisfaction towards safety norms

\section{Research Methodology}

The research process consists of the number of selected steps, which are essentially inter-dependent. The collection of facts and information will be followed by processing using scientific technique and tools arrive at reasonable conclusion. The research design used in the study is Descriptive in nature. The data were collected from both primary and secondary sources. Structured questionnaire was distributed to a sample of 70 employees working in BGR Energy Systems to collect Primary Data using Convenient Sampling Technique. The secondary data were sourced from websites, journals, magazines, articles, and media report.

\section{Scope of the Study}

The scope of the study gains more attention as the study focusses on the deficiency of the welfare measures which can be identified and suitable recommendations can be made. This study was conducted by the researcher in BGR Energy Systems at Chennai

\section{Need of the Study}

Welfare Measures are provided by Organsiations to promote the physical, Psychological and general well-being of employees. The present study is an analysis of the effectiveness of employee welfare measures and QWL of work force in the Organsiation, which serves as an effective feedback to the Management.

\section{Limitations of the Study}

- Due to Time Constraints, the survey was restricted to 70 respondents from the universe

- As the questions were direct to the personal opinion of the employees, some of them were hesitant to respond

- Meeting the employees personally was difficult during their working hours

\section{Review of Literature}

Dr. S. Ravi (2016) Volume: 05, Issue: 01 "A Study on Employee Welfare Measures with reference to small scale industries at Hosur,Tamilnadu - Labour welfare measures prove to be an important factor when compared to the other factors in the organization. These measures operate to neutralize the harmful effects to large scale industrialization and urbanization. Thus, these measures to an organization are one of the factors for the workers towards success of the organization."

Arpit Patel (2017) Volume: 06, Issue: 01 "A Study on Labour Welfare Measures and Social security on selected engineering unit of Ahmedabad - According to his study "welfare measures is maintaining relationship among employee for purpose of production, efficient production and human well- being and industrial growth. There must be various welfare measures and social security which are considered to maintain harmony among employees and employers.

B.R. Manasa (2015) Volume: 02, Issue: 09 "A study on employee welfare measures with reference to cement corporation of India units in Thandur and Abilabad According to her study the welfare measures should be provided to both permanent and temporary employees in such a way that employees become satisfied about employee welfare facilities. It increases productivity as well as quality and quantity. Welfare measures improve the performance level of the employees which leads to improve favorable effects of profitability, products of the organization and to accomplish the organization goals."

E. Sivakalyankumar (2019) Volume: 06, Issue: 03 "A study on employee welfare measures at rashtriya is patnigam ltd (RINL) Vishakhapatnam" - His study reveals that the employee opinion towards labour welfare facilities offered by RINL STEEL PLANT, it has three objectives to measure the complete welfare facilities. First objective tries to observe the knowledge and awareness of labour welfare facilities provided by the organization. It reveals that adequate level of awareness found among employees. The observation state that working condition is pleasant, wages is good compared to similar industry, management - employee relationship is quite decent, facilities provided for labours were also satisfactory.

Mridul Mishra (2016) Volume: 47, No.1-2 "A study on labour welfare measures and its effect on employee's job satisfaction in an industry of district Faridabad" - they stated that labour welfare cannot be limited to facilities within or near the undertaking nor can it be so comprehensive as to embrace the whole range of social welfare or social services. The measures such as creation of advanced research facilities, human 
resource development, creation of environmental and occupational health cells and development of database and information system should also be considered.

Mrs. S. Jaishree (2015) Volume: 03, Issue-04 "A study on labour welfare measures and its impact on employee's job satisfaction in garment industries, Tirupur - The labour welfare practices aims on fair wages, good working conditions and realistic terms and conditions of employment. It is concluded that the labour welfare practices followed in the industries in satisfactory.

RamyaT.J(2016) Volume:06,Issueno.12"A study on employee welfare facilities and its impact on employee satisfactory at hotel industry with special reference to Mysore district - In this study it is found that workers were fulfilled by the approach of employee welfare procedures taken for the workers. The welfare measures schemes are significant characteristic in each association which performs a very imperative role and such welfare schemes efficiently get better recital of the workers and assist the business in imprison the good advertising in modern antagonism.

Dr. R. K. Lalitha (2014) Volume: 02, Issue: 07 "A study on employee welfare measures with reference to IT industry" Stated that the worker welfare amenities are challenge to this branch, if the workers are joyful with welfare services then only the constructiveness of that agency can be expanded. Foundations on the learning of the worker welfare facilities in IT enterprise it is apparent that the business is very intense in the encourage welfare activated by IT industry.

\section{Data Analysis \& Interpretation}

Table: 1

Facilities Provided by the Organisation using Weighted Mean

\begin{tabular}{|c|c|c|c|c|}
\hline Facilities & $\begin{array}{c}\text { Highly } \\
\text { Satisfied }\end{array}$ & Satisfied & Neutral & Rank \\
\hline Resting Facilities & 32 & 37 & 1 & 20.7 \\
\hline Sick Leave & 26 & 42 & 2 & 20.3 \\
\hline Education & 33 & 37 & & 20.9 \\
\hline Water & 37 & 30 & 3 & 20.9 \\
\hline Maternity & 30 & 26 & 14 & 19.7 \\
\hline $\begin{array}{c}\text { Security \& Growth } \\
\text { Opportunities }\end{array}$ & 53 & 17 & 0 & 22.2 \\
\hline Fire Extinguisher & 30 & 39 & 1 & 20.6 \\
\hline Safety Equipment & 38 & 32 & 0 & 21.2 \\
\hline
\end{tabular}

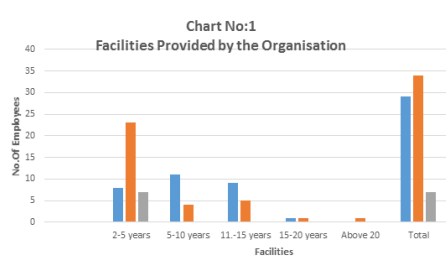

Table: 2 Relationship Between Experience and Level of Satisfaction towards Work Environment

\begin{tabular}{|c|c|c|c|c|c|c|}
\hline $\begin{array}{c}\text { Experie } \\
\text { nce }\end{array}$ & \multicolumn{7}{|c|}{ Work Environment } \\
\cline { 2 - 7 } & $\begin{array}{r}\text { Satisfi } \\
\text { ed }\end{array}$ & $\begin{array}{r}\text { Highly } \\
\text { Satisfi } \\
\text { ed }\end{array}$ & $\begin{array}{c}\text { Neutr } \\
\text { al }\end{array}$ & $\begin{array}{c}\text { Dissatis } \\
\text { fied }\end{array}$ & $\begin{array}{c}\text { Highly } \\
\text { Dissatisfi } \\
\text { ed }\end{array}$ & Total \\
\hline $\begin{array}{c}2-5 \\
\text { years }\end{array}$ & 8 & 23 & 7 & 0 & 0 & 38 \\
\hline $\begin{array}{c}5-10 \\
\text { years }\end{array}$ & 11 & 4 & 0 & 0 & 0 & 15 \\
\hline
\end{tabular}

\begin{tabular}{|c|c|c|c|c|c|c|}
\hline $\begin{array}{c}11 .-15 \\
\text { years }\end{array}$ & 9 & 5 & 0 & 0 & 0 & 14 \\
\hline $\begin{array}{c}15-20 \\
\text { years }\end{array}$ & 1 & 1 & 0 & 0 & 0 & 2 \\
\hline $\begin{array}{c}\text { Above } \\
20\end{array}$ & 0 & 1 & 0 & 0 & 0 & 1 \\
\hline Total & 29 & 34 & 7 & 0 & 0 & 70 \\
\hline
\end{tabular}

Chi-square value :14.91, Degree of Freedom:12, Table value:21.026

Result

The result of the chi-square test reveals that the calculated Chi-Square value(14.91) is less than the table chi-square value(21.03) at $5 \%$ level of Significance and therefore the relationship between Experience and Level of Satisfaction towards Work Environment is not significant. Thus the hypothesis is that relationship between Experience and satisfaction towards Work Environment does not hold good. Thus the Null Hypothesis is Accepted.

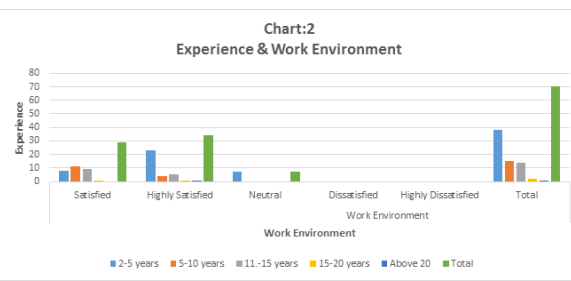

Table: 3 Correlation between Age and Opportunities in BGR Energy Systems

\begin{tabular}{|c|c|c|c|c|c|c|}
\hline $\mathrm{x}$ & $\mathrm{y}$ & $\mathrm{dx}=\mathrm{x}-\mathrm{A}$ & $\mathrm{dy}=\mathrm{y}-\mathrm{A}$ & $\mathrm{d}$ & $\mathrm{d}$ & $\mathrm{dxdy}$ \\
\hline 12 & 28 & -9 & 24 & 81 & 784 & -216 \\
\hline 27 & 38 & 6 & 34 & 36 & 1444 & 204 \\
\hline 21 & 4 & 0 & 0 & 0 & 16 & 0 \\
\hline 7 & 0 & -14 & -4 & 196 & 0 & 56 \\
\hline 3 & 0 & -18 & -4 & 324 & 0 & 72 \\
\hline
\end{tabular}

Correlation between two variables $\mathrm{r}=-2.14$

\section{Result}

The Correlation between two variables Age and Opportunities are negatively associated each other which implies that in BGR Energy systems the opportunities for employees does not depend on the Age factor. Every employee is provided with any kind of opportunities irrespective of Age Factor.

Table: 4 Relationship between Experience and level of satisfaction towards Transportation

\begin{tabular}{|c|c|c|c|}
\hline Experience(x) & Transportation(y) & $\mathrm{X}^{2}$ & $\mathrm{Y}^{2}$ \\
\hline 38 & 70 & 1444 & 4900 \\
\hline 15 & 0 & 225 & 0 \\
\hline 14 & 0 & 196 & 0 \\
\hline 2 & 0 & 4 & 0 \\
\hline 1 & 0 & 1 & 0 \\
\hline
\end{tabular}

T-Test Value: -0.03, Degree of Freedom:5, Table Value: 2.571

\section{Result}

The result of the chi-square test reveals that the calculated TTest value (-0.03) is less than the table T-Test value (2.571) at $5 \%$ level of Significance and therefore the relationship between Experience and Level of Satisfaction towards Transportation is not significant. Thus the hypothesis is that relationship between Experience and level of satisfaction towards Work Environment does not hold good. Thus, the Null Hypothesis is Accepted.

\section{Findings of the Study}

- All employees (100 percent) accepted with the fact that welfare measures promote their physical, intellectual, economic and moral well- being 
- All employees (100 percent) were satisfied with the education facilities.

- Most of the employees(59percent) were comfortable with the suitable ventilation facilities provided in accordance with the work nature of the Organisation

- It was found that most of the employees (53 percent) were satisfied with the drinking water and allowances to rest during working hours provided by the company

- It was found that most of the employees (60 percent) were satisfied with the sick leave

- It was found that most of the employees (54 percent) agreed that sufficient opportunities were provided by the company to improve their skills and knowledge in the relevant field.

- It was found that most of the employees (53 percent) agreed that all the facilities were easily accessible in the work place.

\section{Suggestions}

- The Management may offer many safety training Programme in order to make employee aware with the safety equipment and norms which are definitely lacking in BGR Energy Systems.

- The company can support and appreciate research work to know employees needs to support and motivate them to work

- Allowances provided to the employees during their working hours can be increased

- The company can concentrate on recreational facilities by investing as per the employee's requirement in order to increase their morale and integrity towards job

- More number of rooms can be provided for the employees for Washing, cleaning and drinking water facilities based on the usage

\section{Conclusion}

Welfare is basically a broad concept, referring to a condition of living of an individual or group, in a desirable and happy state of relationship with the whole environment. It helps to motivate and retain the employees This ensures employees satisfaction result in increased efficiency in their QWL. Labour welfare is anything done for the comfort and improvement of employees. Labour comprises all human efforts of body and mind, which are exchanged for a consideration of each or kind or both. This study reveals employee's opinion towards labour welfare measures offered by BGR Energy System Ltd. Further, it has three objectives to measure the complete welfare facilities.

First objectives try to observe the knowledge and awareness of labour welfare facilities provided by the organization. It reveals that adequate level of awareness found among employees. Lack of awareness of safety and absence of transportation facilities are noted. A successful human resource contributes to a powerful labour welfare and smooth industrial relations. This helps the company to grow successfully in accomplishing its goals and further enter into society in an endeavor to uplift the community and humanity. The outcome of this study exhibits employees were more satisfied with their job and some extent aware of labour welfare facilities offered by the organization.

\section{References}

1. Arun Monappa. (1990). Employee welfare and social security in industrial relations. New Delhi: Tata McGraw-Hill Publishing Company Limited.

2. Tripathi, P.C. (1998). Employee welfare and social security, personnel management and industrial relations. New Delhi: Sultan Chand \& Sons.

3. Satayanarayan M.R. and Redhi R.J. (2012): Labour welfare measure in cement industries in India. IJPSS Jour. Vol. 2 (7) PP. 257-254.

4. Anil Kumar [2013] "A study of labour welfare measures in the corporate sector", Asian-African journal of economics and econometrics,

5. Meenakshiyadav and Anil Kumar [2013] "A study of labour welfare measures in the corporate sector", Asian-African journal of economics 